\title{
Meningkatkan Kompotensi dalam Membentuk Opini Publik di Lembaga Kursus dan Pelatihan Public Relations
}

\author{
Yolanda Mario Putri \\ Universitas Negeri Padang \\ Indonesia \\ E-mail : yolandamario02@gmail.com
}

\begin{abstract}
Abstrak-The purpose of this article is to look at business opportunities about public relations courses and training institutions which are the best alternatives for dealing with competition in the workforce. public relations training that constantly improves and updates the curriculum and job seeker resources to have more competencies that have the opportunity to be hired. A Public Relations is needed in an organization or company to be able to create public opinion that can benefit the organization or company concerned.
\end{abstract}

Keywords - Entrepreneur, public relations, public opinion, public relations training

\section{Pendahuluan}

Dalam UU No. 20 Tahun 2003 tentang SISDIKNAS, Pendidikan adalah usaha sadar dan terencana untuk mewujudkan suasana belajar dan proses pembelajaran agar peserta didik secara aktif mengembangkan potensi dirinya untuk memiliki kekuatan spiritual keagamaan, pengendalian diri, kepribadian, kecerdasan, akhlak mulia, serta keterampilan yang diperlukan dirinya, masyarakat, bangsa dan negara. Pendidikan terdiri dari 3 jenis, yaitu pendidikan formal, pendidikan nonformal, dan pendidikan informal. Perbedaan dari ketiga pendidikan ini adalah pada karakteristik peserta didik dan sistem belajar. Tetapi ketiga jenis pendidikan ini memiliki tujuan yang sama, yaitu untuk mengembangkan potensi diri. Potensi yang dikembangkan akan memberikan keterampilan, pengetahuan dan sikap yang akan berguna untuk masa depan terutama dalam mencari pekerjaan.

Lembaga Kursus dan Pelatihan (LKP) merupakan satu bentuk satuan Pendidikan Nonformal yang diselenggarakan bagi masyarakat yang memerlukan bekal pengetahuan, keterampilan, kecapakapan hidup, dan sikap untuk mengembangkan diri, mengembangkan profesi, bekerja, usaha mandiri, dan/atau melanjutkan ke jenjang yang lebih tinggi. Sebagai salah satu satuan Pendidikan Nonformal yang menyiapkan tenaga kerja, LKP dituntut mampu menghasilkan lulusan sebagaimana yang diharapkan oleh dunia kerja. Dunia kerja membutuhkan tenaga kerja yang memiliki kompetensi sesuai dengan bidang pekerjaannya, memiliki daya adaptasi dan daya saing yang tinggi. Atas dasar itu, LKP perlu terus menerus meningkatkan mutu kinerjanya sehingga harapan masyarakat terutama dunia kerja tersebut dapat terpenuhi.

Persaingan yang semakin ketat di dunia kerja bagi pemula dan daya serap pekerjaan yang ada, dituntut semakin baiknya kompetensi yang dimiliki SDM. Pengetahuan, keterampilan dan pengalaman sebagai persyaratan yang diminta untuk bekerja, selain tentunya soft skill tertentu. Pandanganpandangan pemilik atau pengambil kebijakan dibidang SDM tidak selamannya sejalan dengan dunia pendidikan, lulusan lembaga-lembaga pendidikan yang senantiasa meningkatkan dan memperbaharui kurikulum dan sumber daya pencari kerja untuk memiliki kompetensi lebih yang memiliki peluang diterima bekerja. Kondisi-kondisi tersebut tentunya dipahami oleh SDM yang mengerti akan Public Relations (PR) sebagai pencari kerja dan sangat dibutuhkan di perusahan-perusahann atau organisasi. Banyak kasus yang melibatkan perusahaanperusahaan besar di Indonesia terkait hubungan dengan para stakeholder dan lingkungannya. untuk mendapatkan hubungan yang harmonis dengan para stakeholder dan mendapatkan reputasi yang baik, salah satunya disebabkan oleh faktor komunikasi seorang Public Relation.

Public Relations atau disebut juga Hubungan Masyarakat (Humas) memiliki standar kompetensi, sehingga dapat meningkatkan kredibilitas, kualitas kerja dan reputasi dengan memberikan kontribusi memadai bagi organisasinnya. Semakin tinggi fungsi yang dapat dilakukan tentunya akan semakin meningkatkan peran dan posisi di perusahaan dan tentunya sangat dibutuhkan seorang Public Relation yang memiliki kemampuan komunikasi yang bagus untuk menciptakan citra perusahaan yang baik. Ini lah yang menjadi peluang besar bagi mereka yang memiliki keterampilan dan pengetahuan yang mendalam dan ahli dibidang Public Relations. Keterampilan yang dimiliki dapat digunakan untuk membuka usaha atau menjadi seorang wirausaha. Kesempatan 
seperti ini bisa mereka manfaatkan dengan membuka wirausaha Lembaga Kursus dan Pelatihan Public Relatios.

\section{Metode Penelitian}

Artikel ilmiah hendaknya disusun dengan metode dan langkah-langkah yang sistematis untuk memudahkan melakukan penelitian. Pada artikel ini, peneliti menggukan metode studi literatur dengan cara mengumpulkan literatur (bahan-bahan materi) yang bersumber dari buku, jurnal, dan sumber lainnya terkait ilmu tentang meningkatkan kompetensi dalam membentuk opini publik di Lembaga Kursus dan Pelatihan Public Relations.

Artikel ini yang terkait dengan pengertian wirausaha, lembaga kursus dan pelatihan, pengertian public relations, fungsi public relations, tugas dan peranan public relations, membentuk opini publik dan lembaga kursus dan pelatihan public relations. Dalam kesempatan ini peneliti menggunakan metode kualitatif deskriptif, yaitu metode yang digunakan untuk mencari unsur-unsur, ciri-ciri dan sifat-sifat suatu fenomena. Metode ini dimulai dari mengumpulkan data, menganalisis data, dan menginterpretasikannya.

\section{KaJian TeOri dan Pembahasan}

\section{A. Pengertian Wirausaha}

Menurut (Robet Hisrich,1995) "Entrepreneur is the process of creating something different with value by devoting the necessary timr and ef-fort, assuming the accompanying financial, psychological, and social risks and receiving the resulting rewards of monetary and personal satisfaction". Maksudnya wirausaha adalah proses menciptakan sesuatu yang berbeda dengan mengabdikan seluruh waktu dan tenaganya disertai dengan menagguung resiko keuangan, kejiwaan, sosial dan menerima balas jasa dalam bentik uang dan kepuasan pribadinya. Lebih lanjut menurut Meredith (dalam Suryana dan Bayu, 2011) wirausaha adalah orangorang yang mempunyai kemampuan melihat dan menilai kesempatan usaha mengumpulkan serta sumber daya yang dibutuhkan guna mengambil keuntungan daripadanya dan mengambil tindakan yang tepat guna memastikan kesuksesan.

Wirausaha menurut Sudjana (2004) (dalam Isa, M. 2013) adalah seseorang dengan kemampuan dalam berkreasi dan inisiatif dalam menciptakan sebuah inovasi dengan melihat peluang yang ada dan berani menghadapi resiko yang bertujuan pada keuntungan yang akan diperoleh. Seorang wirausaha merupakan seseorang yang memiliki jiwa dan kemampuan tertentu dalam berkreasi dan berinovasi. Ia adalah seseorang yang memiliki kemampuan untuk menciptakan sesuatu yang baru dan berbeda atau kemampuan kreatif dan inovatif.

\section{B. Lembaga Kursus dan Pelatihan}

Dalam Permendiknas Nomor 81 Tahun 2013, Lembaga Kursus dan Pelatihan (LKP) adalah satu bentuk satuan Pendidikan Nonformal yang diselenggarakan bagi masyarakat yang memerlukan bekal pengetahuan, keterampilan, kecapakapan hidup, dan sikap untuk mengembangkan diri, mengembangkan profesi, bekerja, usaha mandiri, dan/atau melanjutkan ke jenjang yang lebih tinggi. Adapun Program pendidikan nonformal adalah layanan pendidikan yang diselenggarakan untuk memberdayakan masyarakat melalui pendidikan kecakapan hidup, pendidikan kepemudaan, pendidikan pemberdayaan perempuan, pendidikan keaksaraan, pendidikan keterampilan dan pelatihan kerja, pendidikan kesetaraan, serta pendidikan lain yang ditujukan untuk mengembangkan kemampuan peserta didik.

Lembaga kursus dan pelatihan menyelenggarakan program pelatihan kerja dan pelatihan lainnya untuk meningkatkan kompetensi kerja baji pencari kerja dan pekerja. Oleh karena itu LKP perlu terus menerus meningkatkan mutu kinerjanya sehingga harapan masyarakat terutama dunia kerja tersebut dapat terpenuhi. Peran LKP sangat diperlukan dalam memenuhi animo masyarakat untuk mendapatkan keterampilan/keahlian yang kompeten untuk memenuhi tuntutan tersebut, sehingga di dalam program jangka panjang sebuah LKP harus mampu mempertahankan eksistensinya dan menjaga keberlangsungannya melalui kemitraan yang digunakan untuk mampu menembus pasar tenaga kerja.

Pasal 103 ayat (1) Peraturan Pemerintah Nomor 17 Tahun 2010 tentang Pengelolaan dan Penyelenggaraan Pendidikan menyebutkan beberapa tujuan dari LKP, diantaranya agar peserta didik dapat yaitu, a) Memperoleh keterampilan kecakapan hidup; b) Mengembangkan sikap dan kepribadian profesional; c) Mempersiapkan diri untuk bekerja; d) Meningkatkan kompetensi vokasional; e) Mempersiapkan diri untuk berusaha mandiri; dan/atau f) Melanjutkan pendidikan ke tingkat yang lebih tinggi.

Sedangkan standar minimal untuk membuka LKP, sudah ditetapkan dalam UU No. 20 tahun 2003, Peraturan Pemerintah, dan Peraturan Menteri terkait adalah sebagai berikut: a) Isi Pendidikan, meliputi: struktur kurikulum yang berbasis kompetensi dan berorientasi pada keunggulan lokal, dan bahan ajar berupa buku/ modul bahan ajar; b) Pendidik dan Tenaga Kependidikan, meliputi; jumlah, kualifikasi, dan kompetensi masing-masing pendidik dan tenaga kependidikan yang sesuai dengan bidangnya; c) Sarana dan prasarana, 
meliputi ketersediaan ruang kantor, ruang belajar teori, ruang praktek, sarana belajar mengajar, dan media pembelajaran, dengan ukuran, jenis, dan jumlah yang sesuai; d) Pembiayaan, meliputi biaya operasional dan biaya personal untuk mendukung terselenggaranya program pendidikan; e) Manajemen meliputi struktur organisasi lembaga dan deskripsi tugas yang jelas dan terarah guna memudahkan jalannya kegiatan dalam pencapaian tujuan; dan f) Proses pendidikan, meliputi: silabus dan rencana Pelaksanaan Pembelajaran (RPP).

\section{Pengertian Public Relations}

Public Relations bisa dikatakan HUMAS (Hubungan Masyarakat), di Negara Indonesia sudah lama dipergunakan secara luas oleh Departemen, Perusahaan, Industri Swasta dan sebagainya. Public relations adalah usaha yang direncanakan secara terus-menerus dengan sengaja, guna membangun dan mempertahankan pengertian timbal balik antara organisasi dan masyarakatnya. Menurut J. C Seidel : Public Relation adalah proses yang berkelanjutan dari usaha manajemen untuk memperoleh jasa baik dan pengertian dari para langganannya, pegawai-pegawinya dan publik umumnya.

Public relations merupakan kegiatan penciptaan pemahaman melalui pengetahuan, dan melalui kegiatankegiatan tersebut diharapkan akan muncul suatu dampak yakni perubahan yang positif. (Jefkins, 2004). Cutlip dkk dalam (Nova,2009:35) mendefinisikan public relations merupakan fungsi manajemen yang membentuk dan memelihara hubungan yang saling menguntungkan antara organisasi dan masyarakat, yang menjadi sandaran keberhasilan atau kegagalannya.

\section{Fungsi Public Relations}

Fungsi utama PR adalah membantu organisasi agar selalu memiliki hubungan harmonis dengan berbagai publiknya melalui kegiatan komunikasi. Konsep PR sebagai komunikasi dua arah menekankan pentingnnya pertukaran komunikasi atau saling memahami dengan penekanan pada penyesuaian organisasi. Hubungan yang demikian itulah, publik sebuah organisasi akan mendukung keberadaan organisasi, programprogram dan kebijakan organisasi. Fungsi PR akan lebih optimal dan mencapai sasaran yang telah ditentukan apabila ditunjang oleh fungsi dan struktur dalam organisasi yaitu duduk sebagai bagian dalam top manajemen (Brammer et al., 2012).

Public relations berfungsi menumbuhkan hubungan baik antara segenap komponen pada suatu lembaga dalam rangka memberikan pengertian, menumbuhkan motivasi dan partisipasi. Semua ini bertujuan untuk menumbuhkan dan mengembangkan pengertian dan kemauan baik (good will) publiknya serta memperoleh opini publik yang menguntungkan atau untuk menciptakan kerjasama berdasarkan hubungan yang baik dengan public (Rachmadi, 1996).

Menurut Griswold dalam (Nova, 2011) fungsi Public Relations antara lain membangun kepercayaan publik terhadap perusahaan.Suatu fungsi manajemen yang menilai sikap publik dan menunjuk kebijakan serta prosedur dari seorang individu atau sebuah lembaga atas dasar kepentingan publik, merencanakan dan menjalankan rencana kerja untuk memproleh pengertian dan dapat diterima dengan baik oleh publik.

Dalam hubungannya public relations dengan organisai dikemukakan oleh Harlow (dalam Ruslan, 2012:16) menyatakan bahwa public relations adalah fungsi manajemen yang khas dan mendukung pembinaan, pemeliharaan jalur bersama antara organisasi dengan publiknya, menyangkut aktivitas komunikasi, pengertian penerimaan dan kerja sama; melibatkan manajemen dalam menghadapi persoalan dan permaslahan, memantu manajemen dalam mengikuti dan memanfaatkan perubahan secara efektif; bertindak sebagai sistem peringatan dini dalam mengantisipasi kecenderungan penggunaan penelitian serta teknik komunikasi yang sehat dan etis sebagai sarana utama.

Kegiatan public relations pada hakekatnya adalah kegiatan komunikasi, tetapi berbeda dengan jenis komunikasi lainnya. Kegiatan komunikasi dalam public relations memiliki ciri-ciri tertentu, disebabkan karena fungsi, sifat-sifat kehumasan yang berlangsung dari sifat-sifat manusia yang terlibat, terutama publik yang menjadi sasaran.

\section{E. Tugas dan Peranan Public Relations}

Adapun tugas public relations adalah: a) Menyelenggarakan dan bertanggungjawab atas penyampaian informasi atau pesan secara lisan, tertulis atau melalui gambar (visual) kepada publik sehingga publik mempunyai pengertian yang benar tentang hal ikhwal perusahaan atau lembaga, segenap tujuan serta kegiatan yang dilakukan; b) Memonitor, merekam dan mengevaluasi tanggapan serta pendapat umum atau masyarakat; c) Mempelajari dan melakukan analisis reaksi publik terhadap kebijakan perusahaan/lembaga, maupun segala macam pendapat (public acceptance dan nonacceptance); d) Menyelenggarakan hubungan yang baik dengan masyarakat dan media massa untuk memperoleh public favour, public opinion dan perubahan sikap. 
Dari uraian tugas public relations di atas, dapat ditarik kesimpulan bahwa public relations mengemban tugas berat untuk menciptakan opini publik yang menguntungkan bagi perusahaan. Tugas tersebut tidak saja dilakukan kepada publik yang berada di luar lembaga, tetapi juga pihak publiknya melakukan kegiatan terhadap lembaga itu, sehingga terjadilah suatu pengertian bersama. Dengan pengertian demikian kita bisa mengetahui adanya sifat komunikasi dua arah dalam public relations. Dalam proses komunikasinya, public relations tidak hanya menyampaikan informasi, tetapi juga menerima informasi dari publiknya.

Aktifitas public relations sehari-hari adalah menyelenggarakan komunikasi timbal balik (two way trafic communications) antara lembaga dengan pihak publik yang bertujuan untuk menciptakan saling pengertian dan dukungan bagi tercapainya suatu tujuan tertentu, kebijakan, kegiatan produksi, dan sebagainya, demi kemajuan lembaga atau citra positif lembaga bersangkutan. Jadi, kegiatan public relations tersebut sangat erat kaitannya dengan pembentukan opini publik dan perubahan sikap dari masyarakat.

Public relations mempunyai peran penting dalam segala bidang sesuai dengan fungsinya, yakni membentuk hubungan yang baik antara organisasi dengan publiknya, baik itu publik internal maupun publik eksternal. Public relations harus dapat memposisikan dirinya antara organisasi dan publiknya, peran public relations akan membayang-bayangi citra sebuah organisasi/perusahaan. Citra perusahaan adalah hal yang penting bagi perusahaan karena menyangkut apa yang dilihat oleh masyarakat, bisa dikatakan juga perusahaan yang mempunyai citra baik di masyarakat tentu akan memiliki kepercayaan yang baik di mata publik eksternalnya.

Secara umum, peranan public relations, baik swasta maupun pemerintah adalah menciptakan opini publik yang menguntungkan perusahaan atau lembaga pemerintah yang bersangkutan. Untuk mencapai tujuan atau sasaran tersebut, perlu diupayakan hubungan yang harmonis antara public relations dan lingkungannya. Public relations harus menekankan moral dan prilaku sebuah citra positif dengan melakukan komunikasi timbal balik kepada publik agar mampu membangun opini, persepsi, dan citra baik (good image) bagi perusahaan (Nova, 2011).

\section{F. Membentuk Opini Publik}

Menurut Bird dalam bukunya The Press \& Society yang dikutip oleh (Abdurrahman,1995) mengatakan bahwa opini publik adalah penilaian sosial (social Judgment) mengenai sesuatu hal yang penting dan berarti atas dasar pertukaran fikiran yang dilakukan individu-individu dengan sadar dan rasionil. Opini publik merupakan sejumlah akumulasi pendapat individual tentang suatu isu dalam pembicaraan secara terbuka dan berpengaruh terhadap sekelompok orang. Dengan demikian, opini publik terbentuk melalui suatu kegiatan berupa debat pembicaraan, atau pertukaran informasi antara individi-individu yang berada dalam suatu kelompok" (Ruslan, 2012:66).

Sehubungan dengan pentingnya opini publik dan dalam public relations, perlu diketahui beberapa hal tentang pengaruhnya dan sifatnya, yaitu : a) Opini publik dapat memperkuat Undang-undang/peraturan-peraturan, sebab tanpa dukungan opini publik, Undang-undang/peraturan-peraturan itu tidak akan jalan; b) Opini publik merupakan pendukung moral dalam masyarakat; c) Opini publik adalah pendukung eksistensi lembaga-lembaga sosial.

Opini dapat dinyatakan secara aktif maupun secara pasif. Opini dapat dinyatakan secara verbal, terbuka dengan katakata yang dapat ditafsirkan secara jelas ataupun melalui pilihan-pilihan kata yang sangat halus dan tidak secara langsung dapat diartikan. Opini dapat pula dinyatakan melalui perilaku, bahasa tubuh, raut muka, simbol-simbol tertulis, pakaian yang dikenakan dan oleh tanda-tanda lain yang tak terbilang jumlahnya, melalui referensi, nilai-nilai, pandangan, sikap dan kesetiaan. Selain itu opini dapat dinyatakan dalam bentuk lain. Opini dapat dinyatakan melalui diskusi informal, melalui surat-surat yang ditujukan kepada redaksi surat kabar secara tertutup, partisipasi pada suatu demonstrasi atau pernyataan pendapat melalui pemogokan karyawan dan sebagainya.

Memahami opini seseorang, apalagi opini publik, bukanlah sesuatu yang sederhana. Seorang praktisi public relations hendaknya dapat memahami secara berkala opini yang tengah beredar di tengah segmen publiknya. Opini tidaklah terbentuk dengan begitu saja secara sederhana. Sebelum seseorang sampai pada tindakan tertentu, orang akan membuka kembali perasaan dan rekamannya yang terbentuk di masa lalu. Maka penting sekali dipahami oleh para praktisi public relations bahwa kegiatan untuk membuat organisasi atau perusahaan disukai oleh publik bukanlah persoalan jangka pendek.

Pembentukan opini tentang citra organisasi/perusahaan dapat dilakukan melalui komunikasi massa dengan menggunakan media cetak yang disebut dengan surat kabar. Media cetak salah satu bentuk dari media yang memiliki segmentasi tersendiri, salah satu bentuk pesan yang memberikan informasi kepada publik dalam bentuk tulisan mengenai masalah-masalah tentang politik, ekonomi atau masalah sosial.

Pembentukan opini tentang citra organisasi melalui komunikasi kelompok melalui proses interaksi sosial yang 
memiliki struktur hubungan sosial yang dinamis menyangkut hubungan antara orang perseorangan, antara kelompokkelompok manusia. Syarat terjadinya intraksi sosial adalah dengan adanya kontak sosial (social contact) dan adanya komunikasi (communication). Sehingga proses komunikasi kelompok di dalam lingkungan masyarakat perlu diciptakan untuk mensosialisasikan program-program organisasi atau perusahaan yang berpihak kepada masyarakat sebagai bentuk kepedulian social organisasi terhadap masyarakat.

Opini publik sangat mempengaruhi suatu lembaga. Penciptaan opini publik yang menguntungkan atau mendukung suatu lembaga adalah tujuan utama public relations. Opini publik atau pendapat umum (public opinion) mempunyai kedudukan yang penting dalam kegiatan penerangan dan public relations.

\section{G. Lembaga Kursus dan Pelatihan Public Relations}

Persaingan saat ini yang semakin ketat di dunia kerja bagi pemula dan daya serap pekerjaan yang ada, dituntut semakin baiknya kompetensi yang dimiliki SDM. Pengetahuan, keterampilan dan pengalaman sebagai persyaratan yang diminta untuk bekerja, selain tentunya soft skill tertentu. Tidak selamannya sejalan dengan dunia pendidikan, lulusan lembaga-lembaga pendidikan yang senantiasa meningkatkan dan memperbaharui kurikulum dan sumber daya pencari kerja untuk memiliki kompetensi lebih yang memiliki peluang diterima bekerja. Kondisi-kondisi tersebut tentunya dipahami oleh SDM yang mengerti akan Public Relations (PR) sebagai pencari kerja dan sangat dibutuhkan di perusahan-perusahann atau organisasi.

Banyak kasus yang melibatkan perusahaan-perusahaan besar di Indonesia terkait hubungan dengan para stakeholder dan lingkungannya. Untuk mendapatkan hubungan yang harmonis dengan para stakeholder dan mendapatkan reputasi yang baik, salah satunya disebabkan oleh seorang Public Relations. Seorang Public Relations sangat dibutuhkan dalam suatu organisasi atau perusahaan untuk dapat menciptakan opini publik yang menguntungkan oganisasi atau perusahaan yang bersangkutan. Oleh sesbab itu banyak organisasi yang sangat membutuhkan seorang Public Relations yang memiliki kompetensi yang baik.

Untuk mendukung perkembangan public relations di Indonesia baik sebagai konsep/teori dan ilmu maupun untuk pembinaan profesional telah berkembang pula lembagalembaga pendidikan dan pelatihan khusus yang mendidik tenaga-tenaga dibidang komunikasi dan public relations pada tingkat akademik di berbagai perguruan tinggi atau universitas maupun pendidikan dan pelatihan yang bersifat kursus-kursus untuk mendidik tenaga terampil di bidang public relations.
Dengan bergabung di Pelatihan Public Relations, ini akan menjadi alternatif terbaik untuk memasuki dunia kerja yang persaingannya semakin ketat. Pelatihan Public Relations ini bertujuan agar sesorang memiliki kemampuan untuk mengkomunikasikan berbagai ide, melaksanakan rancangan program kepada berbagai kelompok masyarakat sasaran organisasi, untuk mendapatkan pengertian dan dukungan, disertai dengan kemampuan untuk mengevaluasi perilaku masyarakat, mengidentifikasikan kebijaksanaan dan prosedur organisasi sesuai dengan kepemtingan masyarakat.

\section{KeSIMPULAN}

Public relations merupakan kegiatan penciptaan pemahaman melalui pengetahuan, dan melalui kegiatankegiatan tersebut diharapkan akan muncul suatu dampak yakni perubahan yang positif. Public relations berfungsi menumbuhkan hubungan baik antara segenap komponen pada suatu lembaga dalam rangka memberikan pengertian, menumbuhkan motivasi dan partisipasi. Semua ini bertujuan untuk menumbuhkan dan mengembangkan pengertian dan kemauan baik publiknya serta memperoleh opini publik yang menguntungkan organisasi/perusahaan. Seorang Public Relations sangat dibutuhkan dalam suatu organisasi atau perusahaan untuk dapat menciptakan opini publik yang dapat menguntungkan oganisasi atau perusahaan yang bersangkutan. Oleh sesbab itu banyak organisasi yang sangat membutuhkan seorang Public Relation yang memiliki kompetensi yang baik. Untuk mendukung perkembangan public relations, pelatihan Public Relations, ini akan menjadi alternatif terbaik untuk memasuki dunia kerja yang persaingannya semakin ketat. Dan bertujuan untuk meningkatkan kompetensi seseorang dalam membentuk opini publik yang dapat menguntungkan organisasi/perusahaan.

\section{Daftar Pustaka}

Abdurrahman, Oemi. (1995). Dasar-dasar Public Relations. Bandung : PT. Citra Aditya Bakti.

Brammer, S., Jackson, G., \& Matten, D. 2012. Corporate social responsibility and institutional theory: new perspectives on private governance. Socio-Economic Review. 10: 3-28.

Isa, Muzakar. (2013). Analisa Kompetensi Kewirausahaan, Orientasi Kewirausahaan, dan Kinerja Industri Mebel. BENEFIT Jurnal Manajemen dan Bisnis Volume 17 No.1.

Jefkins, Frank., 2004. Public Relatins. Jakarta : Erlangga. 
Peraturan Pemerintah Nomor 17 Tahun 2010 tentang Pengelolaan dan Penyelenggaraan Pendidikan.

Rachmadi, F. (1996). Public Relations Dalam Teori dan Praktek, Aplikasi dalam Badan Usaha Swasta dan Lembaga Pemerintah. Jakarta : PT. Gramedia Pustaka Utama.

Robert D. Hisrich dan Michael P.Peter, 1995.
Ruslan, Rosady., 2012. Manajeman Public Relations dan Media Komunikasi. Jakarta: Raja Grafindo.

Sunarya dkk. 2011. Kewirausahaan. Yogyakarta: CV. Andi Offset.

UU No. 20 Tahun 2003 tentang SISDIKNAS 